\title{
The Effect of Financial Knowledge, Financial Behavior, and Religiosity on Personal Financial Distress in the Millenial Generation (Case Study in the Community of Semarang City)
}

\author{
Sukma Kharisma Beny \\ Bank BPD Jateng School of Economics \\ Soekarno Hatta Road Number 88, Semarang \\ 59160, Central Java, Indonesia \\ sukmakharisma25@gmail.com
}

\author{
Siti Puryandani \\ Bank BPD Jateng School of Economics \\ Soekarno Hatta Road Number 88, Semarang \\ 59160, Central Java, Indonesia \\ sitipuryandani@gmail.com
}

\begin{abstract}
The research was conducted to ascertain the influence of financial knowledge, financial behavior, and religiosity on personal financial distress in millennial generation group in City of Semarang. The research population was the millennial generation living in the city. The sampling technique applied was snowball sampling with 100 people aged 20 to 39 years as the sample. The analysis of research data was done through validity test, reliability test, multiple linear regression, classical assumption test, goodness of fit model test, and test. The conclusions of the study were : Negatively and significantly financial knowledge influenced personal financial distress. negatively and significantly financial behavior influenced personal financial distress. Positively but insignificantly, religiosity influenced personal financial distress.
\end{abstract}

Keywords: financial knowledge; financial behavior; religiosity; personal financial distress

\section{INTRODUCTION}

Semarang City is a city with fairly fast economic growth rate. Central Statistics Agency recorded that its economic growth was the highest among all cities in Central Java Province. In addition, it contributed the highest to Central Javas economic growth, 13,45\%. The good economic performance of Semarang City had a positive impact on improving the welfare of the people. It was indicated by an increase in peoples income which then became a driving factor for increasing the level of public welfare. However, the increase in the income of the people of Semarang City had made the people more consumptive. A consumptive life style can threaten the lives of millennial people. A consumptive life style increases the probability of bad credit risk when someone applies for credit, but the goal is only to meet lifestyle needs and expenses are made to live in luxury beyond their income ability [14]. According to a survey by Kadence International Indonesia involving 3000 respondents from the lower class to the upper class, it was stated that $28 \%$ of Indonesians were the group with more expenditures than income, so it had a deficit of about 35\% [6]. Financial distress generally occurs due to financial insufficiency in fulfilling various needs. Financial insufficiency to meet various needs will be a major factor in public financial distress, especially in the city of Semarang who display a high life style.
There are several kinds of theories to support this research:

- Prospect Theory

Developed by Kahneman and Tversky prospect theory in psychology which discussed irrational behavior. Prospect theory was based on an analysis of a persons behavior in making economic decisions in risk and uncertain conditions [5]. Prospect theory was devoted to behavioral economics which stated than not all economic actors were rational. In another sentence, economic actors did not only view from a rational or irrational side but also from various broader aspects.

\section{- $\quad$ Social Learning Theory}

The theory was developed by A. Bandura, where this theory was mainly based on various principles of learning behavior theory. However, it emphasized the various impacts of various signs displayed on behavior and internal mental processes [2]. One of the earliest assumptions underlying Banduras version of social learning theory was that humans weres flexible enough and able to learn how behavioral or behavioral skills should be displayed. Based on social learning theory, there was three-way relationship that was interrelated. They were behavior, environment, and events that affected perceptions and actions.

\section{- Personal Finance}

According to T.K. Khairunnisa, personal finance is an application of financial principles in making financial decisions for individuals or family units. In personal finance, it was explained how individuals or families obtain, budget, save, and spend financial resources. Afterwars, they recorded various financial risks and so future events [6].

\section{- Millenial Generation}

According to I.A. Walidah, millennial is a term for cohort in demography and it means a follower or a group. At the present, there are 4 cohorts in demography, namely baby boomers, Gen-X, Millennials (born in 1981 until 2000), and Gen-Z [13]. The current millennial generation (2020) is those aged 20 until 39 years.

- Financial Distress

According to S. Stamp, financial distress is a condition that occurs due to a lack of personal responsibility such as 
difficulties in budgeting and financial management, affluent attitudes in managing money, and over courage when applying for credit. In addition, financial distress can also occur because someone does not have a job, being sick, increases unplanned bills, and failure to manage business [12].

\section{- Financial Knowledge}

According to N. Lajuni, financial knowledge is knowledge that refers to what individuals know related to personal financial problems and it is measured by the level of knowledge about various personal financial concepts [8].

\section{- Financial Behavior}

According to A.H. Manurung financial behavior was a study that learnt how phenomena in psychology influenced financial behavior [10].

\section{- Religiosity}

According to T.K. Khairunnisa, G.N. Ahmad, and E. Gurendawati, religiosity was an orientation, a series of behaviors, and a life style that was considered important by some individuals around the world that social and personality psychology could not ignore [6].

A. Hypotheses

H1 : Negatively, financial knowledge influences personal financial distress of millennial generation in Semarang City.

H2 : Negatively, financial behavior influences personal financial distress of millennial generation in Semarang City.

H3 : Negatively, religiosity influences personal financial distress of millennial generation in Semarang City.

\section{METHODOLOGY}

The population of research was the millennials of Semarang City. They were a group of people aged 20 until 39 years in 2020 [12]. The total population was 632.246 people in 2019 [13]. The sampling technique applied was nonprobability sampling through snowball sampling method. The sampling method referred to the Slovin approach and the number of samples obtained was 100. Primary data was obtained through online questionnaires which were guided by Google Form and distributed through social medias. The measuring instrument used in this study was Likert scale. The Likert scale consists of (1) strongly disagree, (2) disagree, (3) neutral, (4) agree, and (5) strongly agree. The study applied descriptive statistical analysis and then testing of the validity and reliability.

Afterward, the data were analyzed through multiple linear regression. Then, the quality of the data was tested through the classical assumption test (normality, heteroscedasticity, and multi collinearity test). Furthermore, testing the goodness of the model (goodnes of fit test) consisting of the coefficient of determination (R2), model fit test (F-test), and partial influence test (t-test) were done. The software used was SPSS (Statistical Package for Social Sciences).

\section{A. Descriptive Statistics}

\section{RESULTS AND DISCUSSIONS}

The characteristics of the respondents were $40 \%$ male and $60 \%$ female. The age range of respondents was dominated by those aged 20 until 25 years $(76 \%)$. Most of the respondents graduated high school education and the equivalent. Currently, they are still students and the others are State Civil Servants / Indonesian National Army / Police, entrepreneurs, and private employees. From aspect of income, 64 respondents $(64 \%)$ had more than Rp. 2.500.000 per month. The average financial knowledge score of the respondents was high, namely $77.97 \%$. Later, the average score for financial behavior of the respondents was good, namely $79.94 \%$. Then, the average religiosity score of the respondents was very high at $85.6 \%$. Furthermore, the average personal financial distress score of the respondents was low, namely $48.26 \%$.

\section{B. Validity and Reliability Tests}

The questionnaire was valid because all statements performed calculated $r$ value that were more than the $r$ table. From the reliability test, the value of Cronbach Alpha X1 was $0,884, \mathrm{X} 2$ was $0,886, \mathrm{X} 3$ was 0,733 , and $\mathrm{Y}$ was 0,898 . They were more than 0,70 as the underlying requirement. Thus, all research variables were reliable.

\section{Classical Assumption Tests}

The normality test was carried out through KolmogorovSmirnov test. With a significance value of 0,200 (more than $0,05)$, it coul be concluded that the data were normally distributed. Through the multi-collinearity test, the tolerance values for the regression model $\mathrm{X} 1, \mathrm{X} 2, \mathrm{X} 3$ to $\mathrm{Y}$ were 0,440 , 0,392 , and 0,820 (more than 0,10 ) and the VIF values were 2,271, 2,554, and 1,219 (less than 10). Therefore, it was concluded that in the study, multi-collinearity among independent variables in the regression model did not occur. The heteroscedasticity test was carried out through the Glejser test. All independent variables performed a significance value of more than 0,05. So, it could be concluded that heteroscedasticity was not detected.

\section{Goodness of Fit Test}

The calculated $\mathrm{F}$ value was 22,904 with a significance probability value of 0,000 . Because the probability value was less than 0,05 , the regression model in the study could predict the value of dependent variable. The value of $\mathrm{R} 2$ was 0,399 . It meant that only $39,9 \%$ of the value of personal financial distress could be explained by financial knowledge, financial behavior, and religiosity. The remaining $60,1 \%$ were various other variables that were not studied in the research.

TABLE 1. MULTIPLE LINEAR REGRESSION ANALYSIS SUMMARY

\begin{tabular}{|c|c|c|c|c|c|}
\hline Variables & $\begin{array}{c}\text { Regressio } \\
\mathbf{n} \\
\text { Coefficien } \\
\text { ts }\end{array}$ & $\begin{array}{c}\mathbf{t}- \\
\text { Calcul } \\
\text { ated }\end{array}$ & Sig & $\begin{array}{c}\text { Std. } \\
\text { Eror }\end{array}$ & $\begin{array}{c}\text { Conclusion } \\
\mathbf{s}\end{array}$ \\
\hline $\begin{array}{c}\text { Financial } \\
\text { Knowledge }\end{array}$ & $-0,405$ & $-3,134$ & 0,002 & 0.129 & Significant \\
\hline $\begin{array}{c}\text { Financial } \\
\text { Behavior }\end{array}$ & $-0,363$ & $-2,700$ & 0,008 & 0,134 & Significant \\
\hline Religiosity & 0,094 & 0,518 & 0,605 & 0,182 & $\begin{array}{c}\text { Not } \\
\text { significant }\end{array}$ \\
\hline $\begin{array}{c}\text { Constant } \\
\text { Adjusted R } \\
\text { F Calculated } \\
\text { Sig }\end{array}$ & $\begin{array}{l}33,651 \\
0,399 \\
22,904 \\
0,000\end{array}$ & & & \\
\hline
\end{tabular}

$\mathrm{Y}=33,651-0,405-0,363+0,094+\mathrm{e}$ 
From regression model equation above, It was concluded that :

1. The coefficient value of financial knowledge (X1) was 0,405 . It indicated that the better financial knowledge, the lower personal financial distress.

2. The coefficient value of financial behavior (X2) was 0,363 . It meant that the better financial behavior, the lower personal financial distress.

3. The coefficient value of the religiosity variable (X3) was 0,094. It indicated that the better a person's religiosity, the higher personal financial distress. When someone had a good religiosity, he tended to help those who were in trouble. Someone with good religiosity would feel satisfied if he could help those who were in trouble. But in the other side and in the real fact, there so many people made disappointment to someone who had helped them. So, the better the religiosity, the higher personal financial distress.

E. Hypotheses Testing

1. Based on t test, the significance probability value of financial knowledge was 0,002 (less than 0,05). Therefore, $\mathrm{H} 0$ was rejected and $\mathrm{H} 1$ is accepted. It was concluded that financial knowledge negatively andmsignificantly influenced personal financial distress. The conclusion was in line with the research results of K.L. Archuleta, N. Lajuni, Y. Yuliani, V. Zahirofic-Herbert [1, 7, 14, 15]. They stated that good financial knowledge could reduce the level of personal financial distress. So, it was be proven that the millennial generation in Semarang City had a good level of financial knowledge. It could make them better in managing their financial matters. With good financial knowledge, the level of personal financial distress could be reduced.

2. From t test, the significance probability value of financial behavior was 0,008 (less than 0,05). Thus, H0 was rejected and $\mathrm{H} 2$ was accepted. It meant that financial behavior had a negative and significant influence on personal financial distress. So, the better someones financial behavior, the lower level of personal financial distress felt. The conclusion was same with research conclusions conducted by K.L. Archuleta, T.K. Khairunnisa, N. Lajuni $[1,6,8]$. They stated that the better someone's financial behavior, the lower level of personal financial distress felt. This meant that if someone wanted to avoid personal financial distress, he should be able to manage financial matters well.

3. Through the t test, the significance probability value of religiosity was 0,605 (more than 0,05 ). Thus, $\mathrm{H} 0$ was accepted and $\mathrm{H} 3$ was rejected. It meant that the more religious a person was, the higher possibility of experiencing personal financial distress. The conclusion was in line with the results of the research T.K.
Khairunnisa, M.F.Sabri [6,11]. Which stated that under certain conditions, religiosity could harm or cause difficulties for someone. Indeed, in other circumstances, religiosity could help a person. Some people experience financial stress because of their religious demands on their time and money.

\section{CONCLUSIONS}

The research was conducted to ensure the influence of financial knowledge, financial behavior, dan religiosity on personal financial distress. Based on the research conducted, some conclusions could be formulated. The were : Negatively and significantly financial knowledge influenced personal financial distress. Negatively and significantly financial behavior influenced personal financial distress. Positively but insignificantly, religiosity influenced personal financial distress.

\section{REFERENCES}

[1] K.L. Archuleta, A. Dale, and S. M. Spann, "Financial Satisfaction, and Financial Anxiety," J. Financ. Couns. Plan., vol. 24, no. 2, pp. 50-62, 2013.

[2] A. Bandura, "Social Foundatioan of Thouhgt and Action: a Social Cognitive Theory", New Jersey: Prentice Hall, Inc, 1986.

[3] S.M. Danes and H. R. Haberman, "Jamestown 7-24-09 Parking Lot View," J. Financ. Couns. Plan., vol. 18, no. 2, pp. 48-60, 2007.

[4] V.I. Dewi, E. Febrian, N. Effendi, and M. Anwar, "Financial literacy among the millennial generation: Relationships between knowledge, skills, attitude, and behavior," Australas. Accounting, Bus. Financ. J., vol. 14 , no. 4, pp. 24-37, 2020.

[5] Kahneman, Daniel dan Amos Tversky, "Prospect Theory: An Analysis of Decision Under Risk. Econometrica”, vol. 47, pp. 263-291, 1979.

[6] T.K. Khairunnisa, G..N. Ahmad, E. Gurendawati, "Pengaruh Religiusitas, Preferensi Risiko, Dan Locus Of Control Terhadap Perilaku Keuangan Dan Dampaknya Terhadap Personal Financial Distress Pada Pekerja Muda Di Dki Jakarta", Jrmsi-Jurnal Riset Manajemen Sains Indonesia, vol. 11, no. 2, pp. 381-403, 2020.

[7] N. Lajuni, I. Bujang, A. A. Karia, and Y. Yacob, "the Role of Educators and the Influence of Financial Behavior on Personal Financial Distress Among Undergrad Students of Public Universities in Sabah , Malaysia," Int. J. Educ. Psychol. Couns., no. December, pp. 121-130, 2017.

[8] N. Lajuni, I. Bujang, A. A. Karia, and Y. Yacob, "Religiosity, Financial Knowledge, and Financial Behavior Influence on Personal Financial Distress Among Millennial Generation," J. Manaj. dan Kewirausahaan, vol. 20, no. 2, pp. 92-98, 2018.

[9] A. LeBaron, H. Kelley, E.J. Hill, Q. Galbraith, "Finances, religion, and the FAAR model: How religion exacerbates and alleviates financial stress," Psychology of Religion and Spirituality, 2019.

[10] A.H. Manurung, "Teori Perilaku Keuangan ( Behaviour Finance )," Econ. Manag., vol. 41, no. 4, pp. 1-13, 2012.

[11] M.F. Sabri, L. Falahati, "Toward a framework of financial wellness determinants: investigating the moderating effect of religion," Australian Journal of Basic and Applied Sciences, vol 8, no. 9, pp. 275-281, 2014.

[12] S. Stamp, "An exploratory analysis of financial difficulties among those living below the poverty line in Ireland,"Combat Poverty Agency Working Paper Series, vol 9, no 2, pp. 1-92, 2009.

[13] I.A. Walidah, "Tabayyun di Era Generasi Millenial", Jurnal Living Hadis, vol. 2 no. 2, 2018.

[14] Y. Yuliani, "The Effect of Financial Knowledge on Financial Literacy with Mediated by Financial Behavior in Society of Palembang City South Sumatera," Mix J. Ilm. Manaj., vol. 9, no. 3, p. 421, 2019.

[15] V. Zahirovic-Herbert, K. M. Gibler, and S. Chatterjee, Financial literacy, risky mortgages, and delinquency in the US during the financial crisis, vol. 9 , no. 2. 2016.

[16] https://semarangkota.bps.go.id/dynamictable/2015/05/20/18/jumlahpenduduk-menurut-kelompok-umur-di-kota-semarang-2012---2019.html 